University of Nebraska - Lincoln

DigitalCommons@University of Nebraska - Lincoln

\title{
Corrigendum to "Distribution and environmental limitations of an amphibian pathogen in the Rocky Mountains, USA" [Biological Conservation 141 (2008) 1484-1492]
}

\author{
Erin Muths \\ USGS-Fort Collins Science Center, muthse@usgs.gov \\ David S. Pilliod \\ Aldo Leopold Wilderness Research Institute, dpilliod@usgs.gov \\ Lauren J. Livo \\ University of Colorado at Boulder
}

Follow this and additional works at: https://digitalcommons.unl.edu/usgsstaffpub

Part of the Earth Sciences Commons

Muths, Erin; Pilliod, David S.; and Livo, Lauren J., "Corrigendum to "Distribution and environmental limitations of an amphibian pathogen in the Rocky Mountains, USA" [Biological Conservation 141 (2008) 1484-1492]" (2008). USGS Staff -- Published Research. 132.

https://digitalcommons.unl.edu/usgsstaffpub/132

This Article is brought to you for free and open access by the US Geological Survey at DigitalCommons@University of Nebraska - Lincoln. It has been accepted for inclusion in USGS Staff -- Published Research by an authorized administrator of DigitalCommons@University of Nebraska - Lincoln. 


\title{
Corrigendum
}

\section{Corrigendum to "Distribution and environmental limitations of an amphibian pathogen in the Rocky Mountains, USA" [Biological Conservation 141 (2008) 1484-1492]}

\author{
Erin Muths ${ }^{a, *}$, David S. Pilliod ${ }^{b}$, Lauren J. Livo ${ }^{c}$ \\ ${ }^{a}$ USGS-Fort Collins Science Center, 2150 Centre Avenue, Building C, Fort Collins, CO 80526, USA \\ bUSDA Forest Service Aldo Leopold Wilderness Research Institute, 790 E Beckwith Avenue, Missoula, MT 59801, USA \\ ${ }^{\mathrm{c}}$ Department of Integrative Physiology, University of Colorado, Boulder, CO 80309-0354, USA
}

\section{The author regrets that in the above published paper the following error occurred:}

In our recently published paper, "Distribution and environmental limitations of an amphibian pathogen in the Rocky Mountains, USA", we erroneously included the paper by J. Bosch et al. (2006), "Climate change and outbreaks of amphibian chytridiomycosis in a montane area of Central Spain: is there a link?" in a list of studies from the tropics. Clearly Dr. Bosch and colleagues worked in the temperate zone at a latitude very similar to that in our study suggesting that further investigation of additional similarities between the two sites might be useful.

DOI of original article: 10.1016/j.biocon.2008.03.011

* Corresponding author: Tel.: +1 970226 9474; fax: +1 9702269230.

E-mail address: muthse@usgs.gov (E. Muths).

0006-3207/\$ - see front matter Published by Elsevier Ltd.

doi:10.1016/j.biocon.2008.09.012 